\title{
THE ROLE OF THE FINANCIAL ENGINEERING INSTRUMENTS IN THE ALLOCATION OF EU FUNDS - THE RESULTS OF THE RESEARCH BASED ON THE EXAMPLE OF THE KUYAVIAN-POMERANIAN VOIVODSHIP
}

\author{
MACIEJ TOKARSKI', PAWEŁ KUFEL ${ }^{2}$
}

\begin{abstract}
The aim of the paper is to present the role of the financial engineering instruments and their implementation in the 2014-2020 financial perspective based on the example of kuyavian-pomeranian voivodeship. The analysis has been based on the reference books on the subject as well as on the results of own research based on the survey questionnaire carried out among the enterprises in the kuyavianpomeranian voivodeship titled: The perspectives of the utilization of the EU funds in the form of the returnable instruments by the enterprises in the kuyavianpomeranian voivodeship for the 2014-2020 financial perspective. The advantages of the financial engineering instruments speak in favor of the amplification of their share in financing within the European Union Funds. However, it shall not mean giving up on subsidies which are indispensable for the financing of various projects. The decision whether to apply the returnable or subsidized financing of the specific undertakings shall be preceded by a detailed analysis, which enables to identify the financial gap in the given sector requiring support.
\end{abstract}

\section{Keywords}

Financial gap; returnable instruments; financial engineering instruments

JEL Classification: G23, H60, P48

1 Doctor, Assistant professor at Institute of Finance, Faculty of Finance and Management, WSB University in
Toruń, Poland. Contact email: maciej.tokarski@wsb.torun.pl.
Doctor, Assistant professor at Institute of Management, Faculty of Finance and Management, WSB University
in Toruń, Poland. Contact email: pawel.kufel@wsb.torun.pl. 


\section{Introduction}

The multi-annual financial plan of the European Union for 2014-2020 provides for the possibility of financing the objectives of the cohesion policy, not only through non-returnable subsidies but also through the use of returnable financing mechanisms. Particular importance is given to non-subsidy instruments, such as credits, loans, and sureties ${ }^{3}$.

In the perspective 2007-2013 in Poland, the financing of projects was possible from the structural funds through subsidies (non-returnable system) and, for the first time, the returnable instruments, also called the financial engineering instruments ${ }^{4}$, were used.

The aim of the article is to present the specificity of returnable financing on the example of financial engineering instruments functioning in Poland in 2007-2013 and their implementation in the financial perspective 2014-2020 on the example of the Kuyavian-Pomeranian Voivodship.

The analysis was based on the literature and the results of own research - using a questionnaire survey conducted among enterprises of the Kuyavian-Pomeranian voivodship - "The prospects for using the European funds in the form of returnable aid by the companies in the Kuyavian-Pomeranian voivodship in the financial perspective 2014-2020".

\section{Concept and Mechanism of European Funds. European Funds for Poland in the Financing Perspective 2004-2020}

One of the objectives of the EU is to strive to equalize the level of development of individual states. The accomplishment of this objective takes place under the EU structural policy. It includes a series of measures aimed at stimulating the longterm socio-economic changes of individual regions and the Member States of the European Union. These measures are to reduce the disparities between regions and remove the delays in the development of the poorest areas. The literature

3 According to estimates by the Ministry of Infrastructure and Development - at present the Ministry of Development - (in the perspective 2014-2020 in Poland, 10\% of the funds allocated from the general EU budget to the cohesion policy will be spent on the returnable aid (for comparison, it was less than $2 \%$ in the ended perspective 2007-2013), and most of the subsidies will be returnable (Bobrowska, 2013: 2; CzykierWierzba, 2013).

$4 \quad$ The concept of financial engineering refers in this case to returnable financing mechanisms created on the basis of combined resources from EU funds and the private capital. The European Commission includes credits, loans, sureties and capital interest offered to beneficiaries under these mechanisms as financial instruments of the financial engineering. In this case, the concept of financial engineering should not be identified with the use of advanced financial science tools, such as derivatives and other alternative instruments. 
The Role of the Financial Engineering Instruments in the Allocation of EU Funds...

distinguishes a regional policy that seeks to increase the economic and social cohesion within the European Union and a cohesion policy aimed at reducing the disparities within the European Union. In practice, however, these concepts are used interchangeably ${ }^{5}$, as their common ultimate objective is the harmonious development of the entire EU.

The structural funds, under which financial resources are distributed between individual regions, include the instruments for implementing the EU structural policy (Regulation no. 1303/2013, Council Regulation no. 1083/2006, Regulation no. 1081/2006, Regulation no. 1080/2006, Regulation of the Minister of Regional Development of 26 October 2011 on the financial aid from the financial engineering instruments under the Regional Operational Programmes).

There are two basic types of funds:

- the European Regional Development Fund (ERDF) - used to finance the so-called "hard projects" within all objectives of the structural policy; it is aimed at reducing the disparities in relation to wealthier regions and reducing the backwardness of the poorest regions, and

- the European Social Fund (ESF) - mainly financing the projects aimed at improving the quality and availability of jobs and reducing unemployment.

The EU structural policy also includes the Cohesion Fund (CF; which is not a structural fund) supporting two areas: environment and transport ${ }^{6}$. However, contrary to the ESF and the ERDF, it is distributed between countries rather than regions. In addition to the structural policy, the EU conducts the Common Agricultural and Fisheries Policy, under which the funds under theEuropean Agricultural Fund for Rural Development (EAFRD) and the European Maritime and Fisheries Fund (EMFF) can be obtained (Regulation no. 1083/2006 laying). Since 2014, the above-mentioned funds have been operating under the common name: the European Structural and Investment Funds (ESIF). This change aims at improving the coordination and harmonization of the implementation of these funds and facilitating their use by the recipients.

The EU budget is set in the seven-year financial perspective. Since its accession to the EU, i.e. 1 May 2004, Poland has participated in the implementation of three

5 One concept was used in the study to define the EU policy - the structural policy - not to introduce terminological chaos.

6 In the perspective 2014-2020, from the amount of EUR 351.8 billion (at current prices) allocated to financing the cohesion policy: EUR 288.4 billion will constitute the structural funds and EUR 63.4 billion will constitute the Cohesion Fund. The main beneficiary of the funds for financing the cohesion policy is Poland, to which EUR 77.6 billion were allocated for this purpose, i.e. $22 \%$ of the total funds allocated to the cohesion policy. It is worth noting that despite the relative reduction in the funds for the cohesion policy, in the current financial framework, compared to 2007-2013, more funds were allocated to Poland (Czykier-Wierzba, 2016: 10-11). 
such budgets 7 . The period and individual amounts that it has already received are as follows (Uryga, Jagielski, Bienias, 2007: 7-8; Tokarski, Tokarski, 2015: 87-105):

- 2004-2006 - Poland received financing at the total amount of PLN 60.5 billion under the National Development Plan. These were mainly preaccession funds under the SAPARD, ISPA and PHARE programmes;

- 2007-2013 - EUR 85.6 billion was allocated for the implementation of the National Cohesion Policy programme to be used by $2015^{8}$;

- 2014-2020 - on 23 May 2014, the Partnership Agreement was approved, under which EUR 82.5 billion were allocated to Poland?.

The EU budget for the financial perspective 2014-2020 is based on 5 main objectives set out in the EU Europe 2020 strategy (Europa 2020; Świstak, 2014: 19-20):

- employment $-75 \%$ of people aged $20-64$ should have a job;

- research and development - at least 3\% of the EU's GDP should be spent on this objective;

- climate changes and sustainable use of energy - reducing greenhouse gas emissions, increasing the share of energy from renewable resources, increasing energy efficiency;

- education - increasing the number of people aged 30-34 with higher education, reducing the number of early school leavers;

- fighting poverty and social exclusion - limiting the number of people at risk of poverty by at least 20 million.

In 2014-2020, 6 programmes financed under the ERDF, the ESF, the CF, the EAFRD, the EMFF, and the ETC programmes will be implemented in Poland at national

Poland is the biggest beneficiary of EU funds. However, the amount of support for Poland per capita is not the highest compared to other Member States (it is higher, among others, in the Czech Republic, Slovakia, Lithuania, Latvia, Estonia, and Hungary).

8 In the financial perspective 2007-2013, the $n+3$ rule was introduced for the first three years of the implementation of operational programmes. This meant that the funds allocated to Poland for 2007 (year $n$ ) could be spent by $2010(n+3)$, resources for 2009 - by 2012, and the funds for 2010 - by 2013 . The $n+2$ rule applied in the following years (i.e. 2011-2013), which means that the final spending period of the funds ended in 2015 (hence the majority of tenders for subsidies from the new perspective 2014-2020 was announced in 2016).

9 The main document in the programming process is the Partnership Agreement, which, like the National Strategic Reference Framework (NSRF) in the previous financing period, defines how the resources of the funds, subject to joint programming, will be spent to achieve the objectives of the Europe 2020 strategy. Unlike the NSRF, the Partnership Agreement also covers agricultural funds and programmes managed by the Commission. 
The Role of the Financial Engineering Instruments in the Allocation of EU Funds...

leve ${ }^{10}$. At regional level, as in the years 2007-2013, 16 ROPs will be implemented ${ }^{11}$. The adopted programme structure is based on positive experience from the programming period 2007-2013 and it is optimally aligned with the objectives of the Partnership Agreement. It also takes into account the integrated thematic and territorial approach as well as the mechanisms of multi-level development policy management functioning in line with the Polish legal order ${ }^{12}$.

\section{Financing Systems Under Which EU Support is Made Available}

In 2007-2013, beneficiaries of the EU aid could take advantage of two forms of support: the non-returnable and returnable financing.

The first form was based on a subsidy mechanism and strongly dominated in the perspective 2007-2013. In general, the submitted applications were assessed in two ways: either in a continuous mode or a tender mode. The continuous mode meant that the applications were accepted and assessed on an ongoing basis - the "first come, first served" principle was predominant. The tender mode is one where, once in a while, the call for applications was announced, and the applicants submitted their applications presenting their undertakings, which were subject to formal and substantive assessment, and the financing was received by beneficiaries whose applications were assessed highest under the available funds allocated for a given tender (Tokarski, Konieczka, 2012: 582; Bera, Tokarski, 2012: 17-20) ${ }^{13}$. In practice, there was a considerable predominance of demand for European funds over their supply. The level of allocation of funds for the implementation of measures under the programmes addressed to enterprises was too small in relation to the needs, which was reflected at least by the number of submitted applications (often the allocation of funds under a given measure was exceeded several or more than a dozen times). Hence the subsidies were available only to a small number of companies.

10 In 2014-2020, the funds under the cohesion policy will be invested in Poland through 6 national operational programmes (OP Infrastructure and Environment EUR 27,513.9 billion, OP Intelligent Development EUR 8,614.1 billion, OP Knowledge Education Development EUR 4,419.3 billion, Eastern Poland EUR 2,117.2 billion, PO Digital Poland EUR 2,255.6 billion, OP Technical Assistance EUR 0.7 billion and regional programmes of voivodeships - ROPs), including one supraregional programme for Eastern Poland voivodeships (Lublin, Podkarpackie, Podlaskie, Świętokrzyskie, and Warmian-Masurian). The Partnership Agreement is the point of reference for them. The national programmes will be managed by the minister competent for regional development.

11 In the current perspective 2014-2020, the financing of operational programmes implemented in the Member States will not take place through one fund, as was the case in 2007-2013, but by pooling the financial resources from the ERDF, the ESF, and the CF.

12 The article does not provide the detailed descriptions of individual programmes of the perspective 20142020 , which can be found on the website of the Ministry of Infrastructure and Development. www.mir.gov.pl/ fundusze/fundusze_europejskie_2014_2020/strony/start.aspx.

13 In practice, there is a significant predominance of demand for European funds over their supply. The level of allocation of the funds for the implementation of measures under the programmes addressed to enterprises is too small in relation to the needs, which is reflected at least by the number of submitted applications (often the allocation of resources under a given measure is exceeded several or more than a dozen times). 
The second form of support is regarded as returnable mechanisms and refers to products defined as financial engineering instruments that are offered by financial intermediaries (banks, loan, and surety funds). The main purpose of these instruments is to increase access to capital. Their characteristic feature is the renewability for subsequent applicants (Pełka, 2012: 224-225). The received funds are repaid by the beneficiary and then re-offered by the intermediary to other entities. Unlike the subsidy support system, the end beneficiary cannot count on the non-returnable aid, but instead, it receives access to the returnable source of financing on preferential terms. The main differences between the two forms of support related to such issues as the returnability of the funds, the type of entity applying for the support, the impact on the conditions of competition, the economic efficiency of the use of a given source of financing. As regards the issue of returnability of funds, the idea is that in the case of new instruments the obtained funds are not allocated forever just to one beneficiary, as in the subsidy system, but they can be used by several entities as a returnable loan provided by a financial intermediary to the beneficiary on terms more favourable than market terms. Thus, in the case of financial engineering instruments, a greater number of end beneficiaries may take advantage of the aid than in the subsidy system (Nicolaides, 2013). The total value of the funds allocated to the financing of the projects is in such a situation higher than in the subsidy system. This allows for a considerable prolongation of the circulation of the funds in the economy, as opposed to the subsidy mechanism in which the granted support cannot be used again by another entity (Szczepański, 2011: 8). The returnability of funds provides for the occurrence of a rollover effect, that is the multiple uses of the same capitals to multiply the value of enterprises. According to EU estimates, the financial instruments worth EUR 2-10 will be created on the basis of each Euro (Instytut Badań nad Gospodarką Rynkową, 2010: 4). It is expected that the resulting multiplier effect will bring far greater benefits to micro, small, and medium-sized enterprises than the subsidy system, by guaranteeing the continuity and stability of the support system. In the entrepreneurs' opinion, the most important feature of returnable instruments is their greater reach than subsidies and improved credit terms (Nicolaides, 2013; Program Rozwoju przedsiębiorstw do 2020 roku, 2014). An element distinguishing the subsidy mechanism from the returnable one is the type of entity that applies for the EU aid. In the case of non-returnable mechanism, entrepreneurs and local governments submit applications if they wish to receive support in the form of EU funds. In contrast to the non-returnable subsidy system, in the case of returnable mechanisms, the financial intermediaries, i.e. banks, business development agencies as well as loan and surety funds, rather than entrepreneurs, apply for the EU funds, who then distribute the funds to SMEs in the form of a loan (including, but not limited to, a micro-credit), sureties or resureties, and the (equitytype) capital entrance (Jaworski, Tokarski, 2014: 103; Dobija, 2014: 80). 
The Role of the Financial Engineering Instruments in the Allocation of EU Funds...

The non-returnable subsidy mechanism can cause disruptions in the competitive conditions. Entities that received a subsidy can eliminate the companies that have not received such support from the market. When using the financial engineering instruments, such a situation does not take place, since the financial resources obtained will have to be repaid on market-like conditions. Compared to the subsidies, the characteristic of the returnable financing is the ability to enforce the economic efficiency of undertakings in which the financial funds are involved. An investor using the loan is forced to ensure such profitability of the implemented investment to enable the repayment of the debt incurred. Too easy access to the subsidies can lead to a situation that the entities are mainly limited to activities aimed at meeting the criteria on which the receipt of support depends, at the expense of the economic efficiency of the financed project. This means the risk of displacing the effective investments by less attractive investments financed by way of subsidies. The returnable instruments also allow financing the investments with a higher level of risk. Therefore, the non-subsidy system will fulfill its role if, on the one hand, it will contribute to raising the efficiency of the absorption of the EU support and, on the other hand, it will allow minimizing the risk of destroying the market (Pełka, 2012: 225-226). Thus, the returnable nature of non-subsidy instruments provides for a higher efficiency of spending of funds compared to the subsidy system. The project implemented by an entrepreneur must be profitable and cost-effective enough to guarantee the repayment of funds obtained.

An important issue related to returnable instruments is the occurrence of the leverage effect associated with the ability to combine public and private financing. This involves the ability to involve private funds in the economic development with the support of public financing with appropriate risk sharing. This process is conducive to building relationships between the parties and greater involvement of private funds in accomplishing the objectives of the cohesion policy.

In conclusion, the inclusion of returnable instruments in the distribution system of EU funds is primarily related to the increased efficiency of the funds used, given the revolving nature of these instruments, which, in the conditions of the fiscal crisis in the European Union countries, is an undeniable asset of this type of funds. It is also important to limit the phenomenon of the so-called capital gap by increasing the availability of micro, small, and medium-sized enterprises for financing, especially start-ups and innovative enterprises without adequate credit collateral. 
Maciej Tokarski, Paweł Kufel

\section{Financial Engineering Instruments in Poland - Past Experience and Objectives For 2014-2020}

The returnable support instruments introduced or planned to be implemented in Poland can be divided into three groups, of which the following are distinguished (Instytut Badań nad Gospodarką Rynkową, 2010: 70):

- loan instruments (global loan for loan funds, global loan for banks);

- surety instruments (resurety for surety funds, portfolio surety for banks);

- capital instruments (capital support of technology transfer funds, capital support of mezzanine funds).

Table 1 The returnable instruments used in Poland in the financial perspective 2007-2013

\begin{tabular}{|c|c|c|c|c|}
\hline Program & Instrument & Objective & Implementing body & $\begin{array}{c}\text { Beneficiaries of } \\
\text { support }\end{array}$ \\
\hline $\begin{array}{l}\text { Regional } \\
\text { Operational } \\
\text { Progras } \\
\end{array}$ & loans, sureties & $\begin{array}{c}\text { increasing the } \\
\text { competitiveness of } \\
\text { enterprises }\end{array}$ & Marshal Offices & $\begin{array}{l}\text { micro, small, and } \\
\text { medium-sized } \\
\text { enterprises }\end{array}$ \\
\hline \multicolumn{5}{|c|}{$\begin{array}{l}\text { JEREMIE } \\
\text { Instrument: Ioans, sureties, resureties, capital instruments } \\
\text { Objective: supporting small and medium-sized enterprises } \\
\text { Implementing body: Bank Gospodarstwa Krajowego (for the Masovian, Lower Silesian, Pomeranian, Greater } \\
\text { Poland, West Pomeranian and Łódź voivodships) and the Kuyavian-Pomeranian Loan Fund (for the Kuyavian- } \\
\text { Pomeranian Voivodship) } \\
\text { Beneficiaries of support: sector of micro, small, and medium-sized enterprises } \\
\text { JESSICA } \\
\text { Instrument: loans, sureties, resureties, capital instruments } \\
\text { Objective: supporting the development of urban areas through the implementation of projects enabling their } \\
\text { sustainable development during urban regeneration and development in the economic and social dimensions } \\
\text { Implementing body: UDFs, that is Urban Development Funds. The following three banks played their role: Bank } \\
\text { Gospodarstwa Krajowego, Bank Ochrony Środowiska and Bank Zachodni WBK. The initiative in Poland was } \\
\text { implemented in } 5 \text { voivodeships: Greater Poland, West Pomeranian, Pomeranian, Silesian and Masovian }\end{array}$} \\
\hline \begin{tabular}{|c|} 
PO IG - Sub- \\
measure 3.4 \\
Venture Capital \\
\end{tabular} & $\begin{array}{l}\text { venture capital } \\
\text { funds }\end{array}$ & $\begin{array}{l}\text { supporting } \\
\text { innovative } \\
\text { enterprises } \\
\end{array}$ & National Capital Funds & $\begin{array}{c}\text { new micro and small } \\
\text { enterprises }\end{array}$ \\
\hline $\begin{array}{c}\text { OP IE - Sub- } \\
\text { measure } 3.1 \text { Seed } \\
\text { Capital } \\
\end{array}$ & $\begin{array}{l}\text { seed capital } \\
\text { funds }\end{array}$ & $\begin{array}{l}\text { development of } \\
\text { new innovative } \\
\text { enterprises }\end{array}$ & National Capital Funds & $\begin{array}{l}\text { new micro and small } \\
\text { enterprises }\end{array}$ \\
\hline $\begin{array}{l}\text { OP IE - Sub- } \\
\text { measure } 4.3 \\
\text { Technological } \\
\text { credit }\end{array}$ & $\begin{array}{l}\text { Technological } \\
\text { credit }\end{array}$ & $\begin{array}{c}\text { supporting the } \\
\text { investments in the } \\
\text { implementation of } \\
\text { new technologies } \\
\text { through granting a } \\
\text { technological credit }\end{array}$ & $\begin{array}{l}\text { Bank Gospodarstwa } \\
\text { Krajowego Department } \\
\text { of European Programs }\end{array}$ & $\begin{array}{l}\text { micro, small, and } \\
\text { medium-sized } \\
\text { enterprises }\end{array}$ \\
\hline $\begin{array}{l}\text { NFEP\&WM/ } \\
\text { VFEP\&WM }\end{array}$ & $\begin{array}{l}\text { loans, credit } \\
\text { lines }\end{array}$ & $\begin{array}{c}\text { environmental } \\
\text { protection and water } \\
\text { management } \\
\end{array}$ & $\begin{array}{c}\text { National Fund for } \\
\text { Environmental Protection } \\
\text { and Water Management }\end{array}$ & $\begin{array}{l}\text { local government } \\
\text { units and enterprises }\end{array}$ \\
\hline
\end{tabular}

Source: Own study. 
The Role of the Financial Engineering Instruments in the Allocation of EU Funds...

Up to now, loan and guarantee products have been used as part of the financial engineering instruments. It should be emphasized that there is also room for the development of other products, including capital ones, which have not been used in Poland yet. However, the first step is to intensify and maximize the support in the form of existing instruments.

In the budgetary perspective 2007-2013, the voivodeships spent PLN 3.52 billion from the EU funds on returnable support instruments. This is very little - less than $1.5 \%$ of all EU money allocated to Poland for 2007-2013. This should change in the current financial perspective 2014-2020 - according to estimates by the Ministry of Infrastructure and Development (at present the Ministry of Development), 10\% of the funds allocated from the general EU budget for the cohesion policy in Poland will be spent on returnable aid, and most of the subsidies will be of returnable nature (Bobrowska, 2013: 2; Czykier-Wierzba, 2013).

From the experience of the financial perspective 2007-2013 in Poland, attention should be paid to the relatively late mobilization of these instruments, with a simultaneous significant increase in interest in them only when subsidy funds are depleted. The limitations of the effective use of the proposed solutions also include the lack of experience with the financial engineering instruments and the lack of methodology for assessing the effectiveness of absorption of European Union funds when used. There is still little awareness and understanding among beneficiaries of EU funds in terms of new returnable instruments.

In the case of financial engineering instruments, up to now in the period 20072013, the returnable aid could only be used by voivodeships in two areas (when supporting small and medium enterprises under the Jeremie Initiative and urban regeneration projects under the Jessica Initiative). In 2014-2020, it will be possible in all the so-called areas of intervention and throughout the programme.

\section{Financial Engineering Instruments in Allocation of European Union Funds - Results of Research Based on the Example of Kuyavian-Pomeranian Voivodship}

In the perspective 2007-2013, the dominant form of obtaining EU funds by entrepreneurs in the voivodship were non-returnable subsidies. Although to a lesser extent, the returnable instruments were also used under two models:

- the first one divided the funds under the ROP into the individual loan and surety funds. Loans or loan sureties were granted from them; 
- the second model is the so-called JEREMIE Initiative. It included a "fund of funds". It was the Kuyavian-Pomeranian Loan Fund, which was entrusted with almost PLN 40 million. It announced a tender procedure for the selection of intermediaries in which various loan, surety or bank institutions took part. They passed these funds on - mostly to entrepreneurs from the SMEs sector. The Kuyavian-Pomeranian Loan Fund (KPLF) disposed of this money in eight tenders, entering into 15 agreements with the intermediaries. It expected from them own contribution, which brought another PLN 12 million for preferential loans for the companies. JEREMIE started with a capital of less than PLN 40 million and, in the end, 579 companies from the Kuyavian-Pomeranian voivodeship received a total amount of about PLN 100 million (www.torun.wyborcza.pl, 2017; Tokarski, Tokarski' 2013: 951110).

In the current perspective 2014-2020, in the Regional Operational Programme the voivodeship has at its disposal EUR 2.23 billion, of which EUR 211 million, that is nearly 10 percent of the budget, was allocated to the returnable instruments. In the first stage, the Marshal Office will transfer them to "funds of the funds' managers", that is public institutions specialized in money management - these are Bank Gospodarstwa Krajowego, the Kuyavian-Pomeranian Development Fund, and the European Investment Bank. The EIB's domain as the "fund of the funds" manager" in the Kuyavian-Pomeranian voivodeship is to be the green economy, that is renewable energy sources and increasing the energy efficiency. Here, the end beneficiaries of money will be not only companies interested in eco-friendly energy solutions but also, for example, communities and cooperatives that need funds for thermal modernization of facilities. In addition, entrepreneurs, government administration, and local government units, as well as non-governmental organizations, will be able to take advantage of loans for financing the construction or modernization of installations for the production, processing, and storage of electricity from renewable energy sources.

In the second stage, they will select intermediaries whose role will be to distribute support directly to companies, in some cases also to other legal entities. The entrepreneurs should receive the financial resources under the returnable instruments in 2018 .

Below are the results of the research carried out among the voivodeship enterprises regarding the possibility of using the returnable funds in the form of financial engineering instruments. The aim of the research was to identify the awareness (knowledge) and needs of companies from the Kuyavian-Pomeranian Voivodeship as regards the functioning and possibilities of using the returnable funds in the form of financial engineering instruments. 
The Role of the Financial Engineering Instruments in the Allocation of EU Funds...

The research was conducted by means of a direct survey among 140 enterprises in the Kuyavian-Pomeranian Voivodeship. $55 \%$ of micro-enterprises, $27 \%$ of small-sized enterprises, $12 \%$ of medium-sized enterprises and $6 \%$ of large-sized enterprises were surveyed. The enterprises of natural persons $(59 \%)$ and in the form of limited liability companies $(25 \%)$ were predominant. Enterprises in the form of a limited liability company (civil partnership, registered partnership, limited partnership and joint stock company) accounted for $11 \%$ of the surveyed companies, while the remaining forms of ownership accounted for $5 \%$ of the sample. The scope of business activity of the surveyed companies is shown in Chart 1 .

\section{Chart 1 Scope of Business Activity}

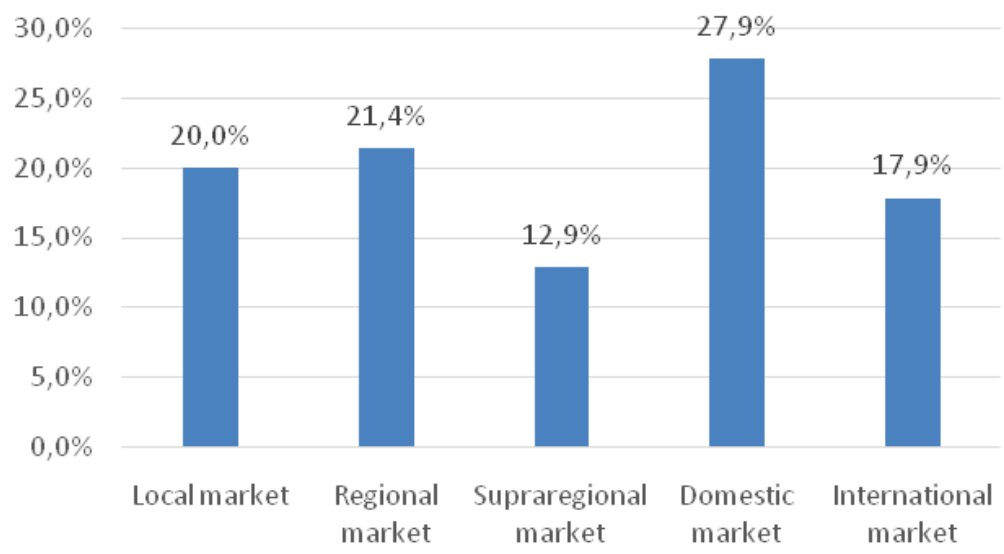

Source: Own study based on the results of the research.

The majority of the surveyed companies were enterprises with only Polish capital (90\%), while the remaining $10 \%$ were companies with foreign or mixed capital. The business activity profile of surveyed companies was as follows: services (59\%), trade (14\%), industry (14\%), services and trade $(6 \%)$, services and industry $(3 \%)$, trade and industry (3\%) as well as services, industry and trade (1\%).

By analyzing the willingness to take advantage of the non-subsidy support among the surveyed enterprises, it can be stated that $71.4 \%$ of surveyed companies have heard about the loan and surety funds. However, there is a significant $57.1 \%$ of enterprises) animosity towards this kind of support. The distribution of the type of non-subsidy support is shown in Chart 3. The main reason for this situation is the lack of interest in support under the Operational Programs of the KuyavianPomeranian voivodeship declared by $67.1 \%$ of enterprises. 
Chart 2 Distribution of Number of Enterprises Willing to Take Advantage of Non-subsidy Support and Expected Forms of Support

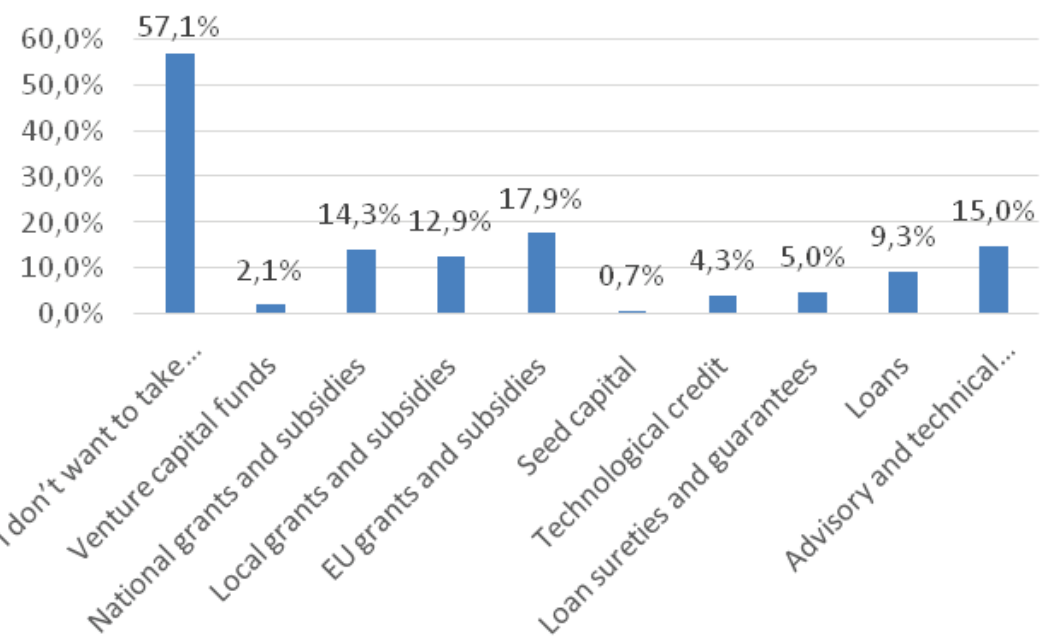

- Local grants and subsidies (e.g. co-financing employment, participation in the costs of trade missions)

- EU grants and subsidies (e.g. co-financing employment, participation in the costs of trade mission)

Source: Own calculations based on the results of the research.

Most entrepreneurs do not recognize and do not want to take advantage of the preferential returnable instruments offered under the programs co-financed from EU funds. The expectation of subsidies as a principal support for business is still predominant, which is due to the fact that, up to now, the non-returnable subsidies were the predominant form in the Kuyavian-Pomeranian Voivodeship in terms of obtaining EU funds by entrepreneurs.

The binary logit model was assessed to determine the factors influencing the willingness to take advantage of the non-subsidy forms of support. The enterprise's declaration on its willingness to take advantage of the support is subject to modeling. Variables that would explain the willingness to take advantage of non-subsidy supports include the size of the enterprise, the legal form, the scope of business activity, the number of employees, the share of foreign capital and the sector. Due to the fact that these variables are of a qualitative nature, dichotomous zero-to-one variables describing the individual states for the described factors were applied. The results of the estimated model are shown in Table 2. 
The Role of the Financial Engineering Instruments in the Allocation of EU Funds...

Table 2 The Estimated Binary Logit Model for the Willingness to Take Advantage of the Non-subsidy Support

Logit estimation, used observations 1-140 $(n=135)$

\begin{tabular}{|l|c|c|c|c|}
\hline & coefficient & Std. error & p-value & End effect* $^{*}$ \\
\hline Drodzaj_2 & 0.83862 & 0.62568 & 0.1801 & 0.20641 \\
\hline Drodzaj_3 & 1.71058 & 1.12305 & 0.1277 & 0.38917 \\
\hline Drodzaj_4 & 0.414102 & 1.4004 & 0.7675 & 0.10302 \\
\hline Dforma_praw_2 & 0.291979 & 0.55406 & 0.5982 & 0.07230 \\
\hline Dforma_praw_3 & -0.347087 & 0.72134 & 0.6304 & -0.08343 \\
\hline Dforma_praw_4 & -1.92191 & 1.34489 & 0.1530 & -0.35051 \\
\hline Dzasieg_1 & 0.602364 & 0.54150 & 0.2660 & 0.14930 \\
\hline Dzasieg_2 & 0.768485 & 0.54261 & 0.1567 & 0.18972 \\
\hline Dzasieg_3 & 0.771709 & 0.62578 & 0.2175 & 0.19052 \\
\hline Dzasieg_5 & 0.666446 & 0.65431 & 0.3084 & 0.16504 \\
\hline Dzatrud_1 & -0.218747 & 0.71019 & 0.7581 & -0.05312 \\
\hline Dzatrud_3 & -0.403567 & 0.56532 & 0.4753 & -0.09707 \\
\hline Dzatrud_4 & -0.123289 & 0.64704 & 0.8489 & -0.03016 \\
\hline Dzatrud_5 & -0.434048 & 0.85379 & 0.6112 & -0.10351 \\
\hline Dzatrud_6 & -1.3775 & 0.97014 & 0.1556 & -0.29041 \\
\hline Dzatrud_7 & -1.65364 & 1.41084 & 0.2412 & -0.32078 \\
\hline Dzatrud_8 & -1.47417 & 1.61319 & 0.3608 & -0.29519 \\
\hline Dbranza_1 & 0.150662 & 0.64791 & 0.8161 & 0.03726 \\
\hline Dbranza_2 & -1.03043 & 0.44062 & 0.0194 & $-0.25102^{* *}$ \\
\hline Dkapital_zagr_1 & -0.210557 & 1.15628 & 0.8555 & -0.05107 \\
\hline Dkapital_zagr_3 & -0.566962 & 1.20065 & 0.6368 & -0.13194 \\
\hline
\end{tabular}

Source: Own calculations based on the results of the research.

The quality of the estimated model is satisfactory - the model correctly predicted $66.7 \%$ of responses. By analyzing the significance of the assessment of structural parameters, only the sector of conducted business activity had a significant impact (at the significance level of 5\%). All other explanatory variables used were found to be statistically insignificant. That means that such factors as the size of the enterprise, the legal form, the scope of business activity, the number of employees, and the share of foreign capital are not decisive in deciding on the willingness to take advantage of the support. The probability that an enterprise providing service is not willing to take advantage of the support is $22 \%$ compared to an enterprise whose business activity is the trade. For other variables (apart from the absence of statistical significance), the following statements can be made: 
- there is a greater likelihood of willingness to take advantage of the support for a small, medium and large-sized enterprise than for a micro-enterprise;

- the number of employees in the enterprise gives a lower probability of taking advantage of the support than if only one person is employed;

- the occurrence of foreign capital in the enterprise resulted in the lower probability of taking advantage of the non-subsidy support than in the case of an enterprise only with Polish capital (it should be emphasized, however, that the variability was very low for this variable - enterprises with only Polish capital were predominant in the survey).

Of the companies that declare their willingness to take advantage of the nonsubsidy support, the main objective of allocating the obtained funds would be the purchase of machinery and equipment (50.9\%) and means of transport $(35.1 \%)$, as well as construction, expansion and modernization of buildings (29.8\%) and the implementation of new technologies (28.1\%). The distribution of responses as regards what the funds would be spent on is shown in Chart 3.

\section{Chart 3 Distribution of Allocation of Financing (it was possible to select more than one answer)}

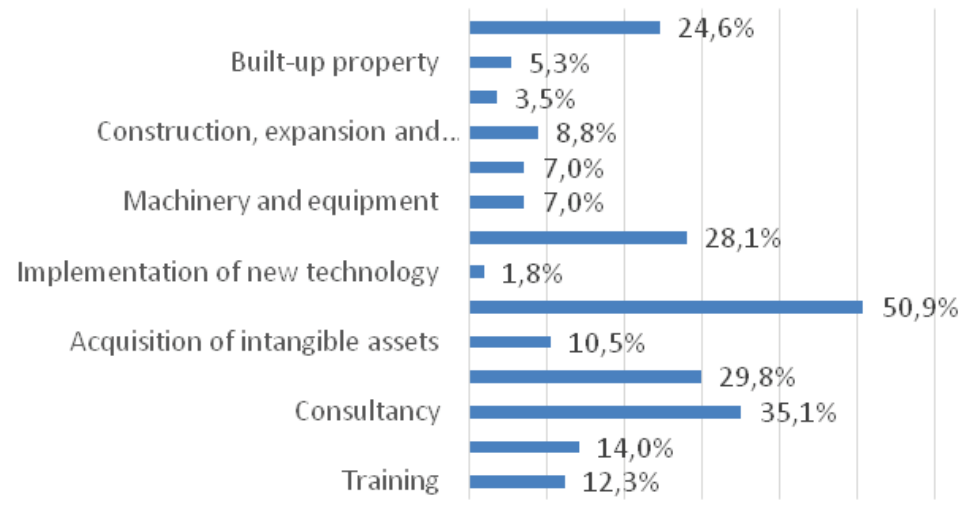

$0,0 \% 10,0 \% 20,0 \% 30,0 \% 40,0 \% 50,0 \% 60,0 \%$

Source: Own calculations based on the results of the research.

\section{Conclusions}

The reasonable use of European funds is one of the tools that can significantly improve the economic situation, especially at local level, and accelerate the 
The Role of the Financial Engineering Instruments in the Allocation of EU Funds...

economic growth. The full use of EU funds allocated to Poland for 2014-2020 creates an opportunity, as shown by experience from the previous multi-annual financial framework, to accelerate the economic growth, increase the competitiveness of the economy and, consequently, limit the distance in the level of economic and social development separating Poland from "old" EU countries. The financial engineering instruments provide an opportunity to increase the access of micro, small, and medium-sized enterprises and local governments to capitals needed to finance their development. This is also an opportunity to reduce the capital gap in the European Union countries.

The most important reason why the European Commission is changing the manner of granting support for the financial engineering instruments of returnable nature is the willingness to increase the efficiency of the use of EU development funds. There are many arguments supporting such a solution. Firstly, the pool of money in EU funds can be multiplied by the fact that these will be returnable funds. Secondly, under such a system, there is a greater chance that the EU support will actually contribute to the economic development and will be allocated to projects that are economically most feasible and guarantee that the granted funds will be multiplied. The subsidy is of a one-off nature, and the returnable instruments can be a system solution.

The inclusion of returnable instruments in the distribution system of European funds is primarily related to the increased efficiency of the funds used, given the revolving nature of these instruments, which is an undeniable asset of this type of resources. It is also important to limit the phenomenon of the so-called capital gap ${ }^{14}$ by increasing the availability of micro, small, and medium-sized enterprises for financing, especially start-ups and innovative enterprises without adequate credit collateral. As demonstrated by experience from 2007-2013, they are more efficient than traditional subsidies. As opposed to the subsidies, they enable multiple uses of financial resources and provide the better quality of the implemented projects, since the credits incurred for the investments must be repaid. This ensures access to the financing for a broader group of entities. The ultimate effect of using the returnable instruments should be increasing the efficiency of the absorption of European Union funds.

The advantages of the financial engineering instruments support the increase in share in financing under the EU funds. This cannot, however, mean a complete abandonment of subsidies that are necessary to finance many types of projects.

14 The gap is connected with the problem of the lack of capital supply, with the existing demand from enterprises that have interesting investment projects. The capital gap problem mainly concerns enterprises in the early stages of development and innovation entities. This is the financial market failure due to information asymmetry between an enterprise and the provider of external capital, resulting in the lack of possibility to obtain funds despite the feasibility of the project to which they are to be allocated. 
A decision to cover certain undertakings with the returnable rather than subsidy financing should be preceded by an analysis that will allow identifying the financial gap in a given sector (Pełka, 2012: 238). Importantly, the use of returnable instruments should in no case be considered as a competition for the subsidy support instruments offered under the Regional Operational Programs. Their role, besides providing additional forms of financing, is to increase the capacity to absorb the funds for small and medium-sized enterprises under the regional programs. The implementation of projects co-financed from the funds under ROPs requires the beneficiary to each time provide own contribution, which is one of the biggest challenges faced by SMEs planning the implementation of investments co-financed from the European funds. And this is where financial engineering instruments that offer relatively easy and inexpensive external financing allowing to create the appropriate financial engineering of undertakings implemented by micro, small, and medium-sized enterprises come to the aid (Gawrychowski, 2017).

Reducing the size of the financial gap in Poland using the returnable instruments should take into account the experience and identified constraints that existed already during the implementation of the above instruments. Otherwise, the potential of returnable instruments for increasing the capital availability for small and mediumsized enterprises will remain unused, and the allocated financial resources will also be unused. The use of returnable instruments is to allow access to external capital for development investments, which can be used multiple times, and the access to it will not be limited by the eligibility of the next financial perspective.

Based on past experience, it is worth to design future returnable instruments to ensure, on the one hand, the high involvement of financial intermediaries and, on the other hand, high interest from the end beneficiaries. To this end, the preparation of central and regional institutions, including, in particular, loan and surety funds as well as cooperative banks, through which funds will be sent to investors, will be of crucial importance for the efficient spending of the funds.

\section{References}

Bera, A., Tokarski, M.: Zaawansowane usługi wsparcia dla mikro, małych i średnich przedsiębiorstw w ramach regionalnych programów operacyjnych na przykładzie województw zachodniopomorskiego i kujawsko-pomorskiego - jak zwiększyć szansę na otrzymanie dotacji? (Advanced support services for micro, small and medium enterprises within the framework of regional operational programs on the example of the Zachodniopomorskie and Kujawsko-Pomorskie voivodships - how to increase the chance of receiving grants?), Zeszyty Naukowe Uniwersytetu Szczecińskiego (Scientific Papers of the University of Szczecin) no. 81 (2012). 
The Role of the Financial Engineering Instruments in the Allocation of EU Funds...

Bobrowska, M.: Fundusze Europejskie w formie pomocy zwrotnej (European funds in the form of repayable aid), Fundusze Europejskie w Polsce (European Funds in Poland) no. 31 (2013).

Czykier-Wierzba, D.: Inicjatywa Jeremie w polityce spójności Unii Europejskiej na lata 2007-2013 i jej funkcjonowanie w Polsce (Jeremie's initiative in cohesion policy of the European Union for 2007-2013 and its functioning in Poland), Journal of Management and Finance no. 2 (2013).

Czykier-Wierzba, D.: Wpływ strategii "Europa 2020” na politykę spójności w Unii Europejskiej w wieloletnich ramach finansowych na lata 2014-2020 i wnioski dla Polski (Impact of the Europe 2020 strategy on cohesion policy in the European Union in the Multiannual Financial Framework 2014-2020 and conclusions for Poland), Journal of Management and Finance no. 14 (2016).

Dobija, E.: Geneza i istota funkcjonowania zwrotnych instrumentów finansowania małych i średnich przedsiębiorstw w Polsce ze środków unijnych: przypadek Jeremie (The origin and essence of the functioning of repayable instruments of financing small and medium enterprises in Poland from EU funds: case of Jeremie), Studia i Prace Kolegium Zarządzania i Finansów SGH w Warszawie (Studies and Works of the Collegium of Management and Finance of the Warsaw School of Economics) no. 139 (2014).

Gawrychowski, M.: Pożyczka zamiast dotacji czyli rozmnażanie euro (Loans instead of subsidies the multiplication of the euro), 2017. www.m.obserwatorfinansowy.pl.

Jaworski, J., Tokarski, M.: Inicjatywa JEREMIE jako forma wsparcia rozwoju mikro, małych i średnich przedsiębiorstw na przykładzie województwa pomorskiego i kujawskopomorskiego (The JEREMIE initiative as a form of support for the development of micro, small and medium enterprises on the example of the Pomeranian and Kujawsko-Pomorskie voivodships), Zeszyty Naukowe Uniwersytetu Szczecińskiego (Zeszyty Naukowe Uniwersytetu Szczecińskiego) no. 111 (2014).

Nicolaides, P.: Financial Engineering Instruments and their Assessment Under EU State Aid Rules. College of Europe, Department of European Economic Studies, Bruges European Economic Policy Briefings no. 26 (2013).

Pełka, W.: Rola instrumentów inżynierii finansowej w alokacji funduszy Unii Europejskiej (The role of financial engineering instruments in the allocation of European Union funds), Studia Biura Analiz Sejmowych (Studies of the Sejm Analysis) no. 31 (2012).

Szczepański, M.: Pozadotacyjne instrumenty finansowe w polityce spójności UE po 2013 r. - wymiar wspólnotowy i krajowy (Adopted financial instruments in EU cohesion policy after 2013 international and national dimension), Warszawa: Ministerstwo Rozwoju Regionalnego, 2011 .

Świstak, M.: Fundusze unijne na lata 2014-2020: programowanie na poziomie unijnym i krajowym (EU funds for 2014-2020: programming at EU and national level), Unia Europejska.pl no. 224 (2014).

Tokarski, A., Tokarski, M.: Barriers and Benefits of Financing projects with European Funds by micro, small, and medium-sized enterprises (MSMEs) in Poland, Journal of Management and Financial Sciences no. 21 (2015). 
Tokarski, M., Konieczka, T.: Działalność inwestycyjna wsparta dotacjami unijnymi a pozycja finansowa przedsiębiorstwa (Investment activity supported by EU grants and financial position of the company), in: Sojaka, S. (eds.): Rachunkowość. Dylematy praktyki gospodarczej (Accounting. Dilemmas of economic practice), Toruń: Wydawnictwo Naukowe Uniwersytetu Mikołaja Kopernika, 2012.

Tokarski, M., Tokarski, A.: Zwiększenie dostępności źródeł finansowania dla sektora mikro, małych i średnich przedsiębiorstw województwa kujawsko-pomorskiego w latach 2007-2013 poprzez fundusz powierniczy JEREMIE (Increasing the availability of financing sources for micro, small and medium enterprises of the Kujawsko-Pomorskie voivodship in the years 2007-2013 through the trust fund JEREMIE), Roczniki Naukowe Wyższej Szkoły Bankowej w Toruniu (Annals School of Banking in Toruń) no. 12 (2013).

Uryga, J., Jagielski, W., Bienias, I.: Środki unijne - klasyfikacja, funkcjonowanie, ewidencja i rozliczanie (EU funds - classification, functioning, accounting and settlement), Gdańsk: Ośrodek Doradztwa i Doskonalenia Kadr Sp. z o.o., 2007.

EU: Council Regulation (EC) no. 1083/2006 laying down general provisions on the European Regional Development Fund, the European Social Fund and the Cohesion Fund, and repealing Regulation (EC) no. 1260/1999.

EU: Regulation (EC) no. 1081/2006 of the European Parliament and of the Council on the European Social Fund and repealing Regulation (EC) no. 1784/1999.

EU: Commission Regulation (EC) no. 1828/2006 laying down detailed rules for the implementation of Council Regulation (EC) no. 1083/2006 laying down general provisions on the European Regional Development Fund, the European Social Fund and the Cohesion Fund as well as Regulation (EC) no. 1080/2006 of the European Parliament and of the Council on the European Regional Development Fund.

EU: Regulation (EU) no. 1303/2013 of the European Parliament and of the Council of 17 December 2013 laying down common provisions on the European Regional Development Fund, the European Social Fund, the Cohesion Fund, the European Agricultural Fund for Rural Development and the European Maritime and Fisheries Fund, as well as laying down general provisions on the European Regional Development Fund, the European Social Fund, the Cohesion Fund and the European Maritime and Fisheries Fund, and repealing Council Regulation (EC) no. 1083/2006.

PL: Regulation of the Minister of Regional Development of 26 October 2011 on the financial aid from the financial engineering instruments under the Regional Operational Programmes. 